investment on Thorp, the oxide fuel plant, which will be vital if Britain is to become a big exporter of its reprocessing services. If business prospects continue to look good, permission will almost certainly be forthcoming.

Cumbria County Council has had a daunting task in assessing the application for planning permission-weighing on the one hand 2,000 jobs in an area of high unemployment and the prospect of much-needed foreign earnings, some of which have already been lost to France through delays, against unfamiliar dangers to a rural community on the other. The Windscale workers have been staunchly in favour of expansion and wanted the County Council to make its decision without further delay. But Friends of the Earth, Half-life, the Conservation Society and the Town and Country Planning Association among others, concerned principally with the oxide plant, wanted the matter referred to a public enquiry.

In the end the committee passed a resolution saying that it was "minded to approve" the application "subject to agreement of appropriate conditions" but passed the final responsibility over to $\mathrm{Mr}$ Shore as the application was a "departure from a fundamental provision of the county development nlan". At the beginning of this week the Department of the Environment said it had still not received formal notification of the Committee's decision. The pressure groups will continue to call for a public inquiry in the little time remaining.

BNFL has been accused by the Lawyer's Ecology Group of providing

\section{Why reprocess?}

The short answer is to make plutonium for fast breeder reactors. Though fast breeders will make us virtually independent of $U_{235}$ sources, the supplies of plutonium and depleted uranium produced by the present generation of thermal reactors are essential for them. But much depleted uranium is treated before use in thermal reactors. Reprocessing also makes environmental sense. The $30 \%$ waste left after the removal of uranium and plutonium is more compact and easily stored than the untreated spent fuel.

A reprocessing works is essentially a straightforward chemical plant with elaborations necessitated by the radioactivity of the materials. The burnt fuel (uranium metal in the case of the Magnox reactors currently in use in Britain, uranium oxide for other reactors including AGRs and PWRs) is dissolved in nitric acid and the uranium and plutonium extracted with an organic solvent. The remaining highly active acid solution containing a variety of $\alpha$ and $\beta$ emitters is at present stored in elaborate stainless steel tanks,

Incorporating the wastes in a solid would allow less hazardous storage, perhaps in deep boreholes either on land or under the sea. Solidification

the County Council with "the sketchiest ever (application) ever offered for any major development" and of leaving it "until all the options were closed". But although the replies to the County Council's detailed questions were only also makes long-distance transport feasible and, if transport of wastes back to their country of origin is made compulsory, will be the sine qua non for Britain's role as a major international processor of nuclear fuels. A process of vitrification developed at Harwell in the late 1950s and known as Harvest has been taken up by British Nuclear Fuels who hope to be constructing a demonstration plant at Windscale by 1980 . But the technological prospect is daunting, combining as it does intense radioactivity with the high temperatures needed for glass making.

Another large question mark hangs over the business of processing oxide fuel which, being more highly irradiated, poses greater problems than Magnox fuel. At present there is no commercial scale oxide fuel reprocessing plant in operation anywhere in the western world, though the La Hague plant opened earlier this year is approaching that level. At Winsdcale a "head-on" plant for preprocessing oxide fuel before it joined the Magnox fuel was in operation, but an accident in 1973 in which a number of workers were contaminated led to the closure of the plant. It is expected to reopen next year.

just ready in time for the public debate, Professor J. H. Fremlin, the County Council's independent scientific consultant, found he had all the information he needed to assess the dangers to the public at large.

\title{
BRITAIN
}

\section{A case of suitable treatment?}

A number of members of the World Federation of Scientific Workers received inexplicable treatment from the Home Office when they tried to enter Britain for the federation's 11th General Assembly on September 17-23. Professor Eric Burhop of University College London, who is President of the federation, gave Nature his view of what happened

THE Federation's General Assembly, its highest policy-determining body, meets every three years. This year, on the occasion of its 30th anniversary and amidst some difficulty for many participants, the assembly was held in London, where the organisation was founded. Professor Burhop tells his story with the aim of preventing another recurrence in the future-the assembly had once experienced even more serious difficulties some 15 years ago.

Before the latest meeting, says Burhop, a British MP associated with the affiliated organisation ASTMS explained to the then Home Secretary, $\mathrm{Mr}$ Roy Jenkins, the nature of the planned meeting and the countries from which the attending scientists would come. That was in February. $\mathrm{Mr}$ Jenkins' reply, according to Burhop, stated that he could see no reason why the assembly should not meet in London; but he added that people coming from countries from which visas were required should make their application in good time and certainly not less than two weeks before they wished to enter Britain, to give time for the necessary processing. "We informed our affiliated organisations accordingly," says Burhop, "and expected there would be no more trouble. It was not until September 14, three days before the Assembly was due to commence, that we began to receive cables from delegates from distant parts that their visas had not been issued."

Burhop is quick to repudiate the frequent charge that the federation is a communist-controlled or Sovietdominated organisation. That is not true, he says, and never has been. $\mathrm{He}$ summarises the aims of the federation as international scientific cooperation, the protection of the freedom and rights of scientific workers, the constructive application of science and international agreement on disarmament and the eventual abolition of nuclear weapons. He describes the attempts of the federation after the Second World War to hold meetings in London to discuss nuclear weapons as "sufficient to send sections of our 
military and political establishment into a flat spin".

Official attitudes appear to have relaxed in recent years, but the federation's latest troubles, as told by Burhop. suggest that it is still viewed with deep suspicion. First to complain of difficulties was an Egyptian professor who had applied in Cairo on July 25 for his visa. Burhop says he received the last of several telegrams from the professor on September 16, saying that owing to the non-arrival of his visa he had cancelled his flight. The professor's visa was finally granted three hours before the commencement of the first meeting he was due to attend. A professor from Vietnam was the next in difficulties. He had applied for his visa five weeks previously at Hanoi, and it was granted on September 16-too late to catch the weekly direct flight from Hanoi to London.

Both professors had visited Britain previously without any difficulty, the Egyptian on many occasions. They were each able to reach London by circuitous routes, but some two days late. Four scientists who formed the delegation of the Organisation of Korean scientists in Japan were not so fortunate. They were members of the community of North Koreans who were stranded in Japan after the Second World War and not allowed to return to North Korea; unlike Japanese nationals, they needed visas to enter the UK, and re-entry permits to return to Japan. The Home Office gave the date of receipt of their visa application as September 2, which allowed the required two weeks for processing; the scientists claim that they applied even earlier. Their visas were granted on September 22, the day before the assembly ended.

But as Burhop points out, Home Office procedures were shown in the oddest light in the handling of the Soviet applications. After the French delegation, the Soviet delegation was the second largest at the Assembly. It consisted of twelve persons, including two Academicians, one a Nobel laureate and another a famous mechanical engineer, a James Watt medallist of the British Institution of Mechanical Engineers. Both members of the Supreme Soviet of the USSR (one is on its Presidium), they had visited Britain many times.

Burhop takes up the story: "There is a discrepancy in dates when the applications are said to have been made. Our Soviet colleagues claim that their Ministry of Foreign Affairs transmitted all the applications together to our Embassy in Moscow on September 3. exactly two weeks before the date of travel as specified by $\mathrm{Mr}$ Jenkins. The Home Office claims that they were received by our Embassy only on
September 8. Late on September 17 I was informed by the Home Office that three of the Soviet visas had been granted, the rest were under consideration, and no more would be granted until Monday. Of the three visas granted two were of secretaries to the delegation. The other was a social scientist and authority on disarmament. The Soviet delegation that sets great store on its distinguished Academicians was deeply offended. It read into the decision a studied insult, which I do not believe was intended, and I feared at one time it might develop into a diplomatic incident. The remaining Soviet visas, with one exception, were granted about midday on September 20 , in time to permit the whole delegation with the exception of the scientist whose visa was refused to travel to London that evening. They were able to make an effective contribution to the rest of the Assembly."

Then there was the GDR delegation, which included the President of the GDR Academy of Sciences and a university rector. Their application was late, and was received only on September 10 . The Polish delegation, however, applied at the same time and received visas almost on time. Visas for the whole of the GDR delegation were granted only on September 21. They arrived the following day and participated only in the tail-end of the assembly.

Burhop again takes up the story: "Of course I do not excuse those delegations who applied late. But some of those who applied very early were also very late in receiving their visas. I was informed by the person handling the visas at the Immigration Department that all the visa applications had arrived on his desk only on September 15 and only then could they begin the usual processing. This was despite the fact that as early as July our office in London had started supplying to the Home Office lists of all the delegates coming from abroad, details concerning whether they needed visas or not and, by early September, the name and country of each participant."

What went wrong? The change of Home Secretary on September 15 may have caused difficulties. The new Home Secretary, Mr Merlyn Rees, was absent from London on September 17 and September 20; it may be that the civil servants whose responsibility it was to take the decision were not willing to do so in the absence of the new minister. But Professor Burhop feels that no matter when the visas were applied for it made no difference: processing of them only started two days before the assembly was due to start and proceeded at a leisurely pace.

The most curious case of all is that of the Soviet delegate, Professor
Grigori Kotowski, whose visa was refused. One newspaper telephoned the Home Office and was told that Professor Kotowski was only an organiser, not a scientist at all. But according to Professor Burhop and others he is a social scientist of great eminence, deputy head of the Institute of the Peoples of Asia of the USSR Academy of Science and a leading authority on India. Kotowski has frequently visited the UK without any trouble, only last year attending on behalf of the USSR an executive meeting of the International Economic History Association.

Burhop speculates that the refusal of his visa was conceivably a matter of bureaucratic face-saving. Having boobed about the issue of visas the Home Office felt it had to refuse one to give the impression that there were very serious reasons for the delay. Alternatively-and less flattering to the Home Office-Burhop suggests a mixup. "The name Grigori Kotowski is very well known in the Soviet Union. It is that of an almost legendary hero, a partisan leader, famed for his military exploits in Moldavia during the Civil War. There is an imposing statue to him in Kishinev. A tank regiment in the Red Army is named after him.

"Professor Grigori Kotowski is his son. A less military looking man or a man more academic or professorial in bearing than Professor Kotowski it would be impossible to imagine. But dare I suggest that the Home Office have got the records mixed up and that when they refused a visa to Professor Grigori Kotowski they mistook him for his father? Of course there is a small matter of fifty years between the careers of the two Kotowskis. Nevertheless in all this matter the Home Office has seemed so maladroit that nothing would surprise me."

The Home Office itself, when contacted by Nature, was hardly illuminating. The applications from North Korea, it admitted, did take a "little bit longer" than others. "We're sorry about it", a spokesman said, but "it took this time to clear. We take our responsibilities very seriously". Asked about the case of Kotowski, he explained that reasons were not given for the refusal of a visa; it depended a lot "on the relationships between one country and another". But he made a suggestion: why didn't Nature give the number of people who did receive their visas on time?

The response is printable. Of the 100 or so people attending, 41 required visas to enter Britain: 16 received their visas in time, 20 received them late and so missed at least 2 days of the assembly, 4 neceived visas too late even to attend, and one had his visa refused. 